\title{
The Neo-Colonial Political Economy of Scholarly Publishing: Its UK- US Origins, Maxwell's Role, and Implications for Sub-Saharan Africa
}

\author{
Eve Gray \\ Senior Research Associate, Intellectual Property Unit, Faculty of Law, University of \\ Cape Town \\ (iD https://orcid.org/0000-0002-2176-0143
}

\begin{abstract}
The prevailing dynamics of today's global scholarly publishing ecosystem were largely established by UK and US publishing interests in the years immediately after the Second World War. With a central role played by publisher Robert Maxwell, the two nations that emerged victorious from the war were able to dilute the power of German-language academic publishing-dominant before the war-and bring English-language scholarship, and in particular English-language journals, to the fore. Driven by intertwined nationalist, commercial, and technological ambitions, English-language academic journals and impact metrics gained preeminence through narratives grounded in ideas of "global" reach and values of "excellence"-while "local" scholarly publishing in sub-Saharan Africa, as in much of the developing world, was marginalised. These dynamics established in the post-war era still largely hold true today, and need to be dismantled in the interests of more equitable global scholarship and socio-economic development.
\end{abstract}

\section{Keywords}

scholarly publishing, academic journals, global science, universities, colonialism, decolonisation, impact metrics, distribution rights, copyright, fair use, fair dealing, Robert Maxwell, UK, US, sub-Saharan Africa, South Africa

DOI: https://doi.org/10.23962/10539/31367

\section{Recommended citation}

Gray, E. (2021). The neo-colonial political economy of scholarly publishing: Its UKUS origins, Maxwell's role, and implications for sub-Saharan Africa. The African Journal of Information and Communication (AJIC), 27, 1-9. https://doi.org/10.23962/10539/31367

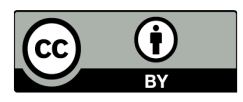

This article is licensed under a Creative Commons Attribution 4.0 International (CC BY 4.0) licence: https://creativecommons.org/licenses/by/4.0 


\section{Introduction}

It is in the political aspirations and the business models that emerged in the wake of the Second World War that one finds the mechanisms that have subsequently tied journals in as a key component of the career promotion systems in academia, thus turning these publications into big business, and entrenching neo-liberal economic thinking into the supposedly esoteric sphere of scholarly publishing.

In the middle years of the 20th century, the dominance of English-language scholarly publishing was shared between Britain and the US. These two powers had, much earlier in the century, forged a clearly neo-colonial "gentlemen's agreement" that international publishing and distribution rights of all kinds were to be divided up between these two powers, with the UK "owning" the Commonwealth as its territory and world market and the US (then very much the junior partner, in a situation that has changed radically since) getting "the rest of the world". At the heart of this system is the story of Robert Maxwell's post-war career, as he was largely responsible for building up journal publication as a large-scale and ultimately very profitable business in the UK and the US, underpinned by business efficiency (see Henderson, 2004). ${ }^{1}$

Maxwell was not the only newly minted journal publishing magnate in the period, but certainly one of the more colourful, and his connection to the wartime British Information Services provides a telling link with neo-colonial political ambitions. Maxwell showed a high level of business skill, transforming the amateur culture of the academic business, in order to build up scholarly publishing as a major cultural-economic player, in line with linguistic and economic nationalism in the post-war period.

What universities and scholars face today is a commercial academic publishing system that exists for the sake of ever-increasing profits, with control, even of internal university faculty promotions, captured by publishing mega-corporations that are among the most profitable and most powerful companies in the world. What is more, with particular relevance for higher education in Africa and elsewhere in the developing world, the contemporary system is decidedly an imperialist inheritance.

\section{The origins and rise of today's global scholarly publishing system}

Scholars often hark back, when seeking to justify the preeminence of journals in today's scholarly publishing ecosystem, to the idealised aims of the original establishment of what was to become the journal system in the English-speaking world.

1 This article relies to a great extent on Henderson (2004) for details of Maxwell's participation in the history of scholarly publishing. 
This was the Philosophical Transactions of the Royal Society of London, first published in $1665 .^{2}$ In reality, it is more accurate to point to a very different 20 th century tradition when locating the underpinnings of the contemporary journal system: an ethos built on post-war English-language nationalism and commercial power, drawing strength from the rise of technological development linked to big business interests. This is a long way from the ideal, espoused in Transactions, of mutual communication within a circle of scholars, whose "engagement in such Studies, and delight in the advancement of Learning and profitable Discoveries, doth entitle them to knowledge of what this Kingdom, or other parts of the World, do, from time to time afford [...]".

The post-war capture of the global journal business placed it in the hands of the two English-speaking victorious powers, the UK and the US, and the ethos, far from being collaborative, is highly competitive-with "excellence" serving as a core value, and an efficient promoter of growing markets and profits for the dominant powers in control of the system. It is a system underpinned by an understanding of the commercial potential of research to grant a competitive edge for technological and scientific advances generating profits and prestige in these nations.

\section{Maxwell and the ascendance of the commercial journal}

Maxwell is best-known as a media magnate and swashbuckling character, rumoured by some to have served as an international double (or triple) agent, who died in 1991 after falling off his yacht in obscure circumstances. Less well-known (except in scholarly publishing circles), but nonetheless an interesting and revealing narrative, is Maxwell's central involvement in the growth of commercial scholarly journal publishing as a business and as a contribution to the intellectual expansion of Britain and the US, as well as other English-speaking powers after the Second World War. What this side of Maxwell's turbulent history reveals vividly is exactly how the post-war development of the political economy of the publishing sector entrenched the English language as the dominant medium of global scholarship and confirmed Britain and the US as the dominant powers whose views and ideologies would inform and direct the sector.

Before the war, German was the dominant language in global science, and Germany was a major force in scientific discovery. When Maxwell emerged on the scene, the German scholarly publishers, who had been hit hard by the war, saw their businesses decimated and their publications expropriated and reproduced outside of the country without payment (Henderson, 2004, pp. 68-69). At the same time, the war had consolidated an understanding of scientific knowledge, and particularly technological research, as an economic force that would be of vital strategic importance in the reconstruction of post-war commerce and political power.

2 Transactions is now available in its entirety online, at https://royalsocietypublishing.org/journal/rstl 3 Although, in the inter-war period, there were robust debates on whether this more open and collaborative approach to drawing benefits from research would be the path to take. 
Maxwell, from a modest background in Czechoslovakia, fought for the Allies in Europe, and after the war-by then a decorated war hero-he worked in the British Zone in Germany for the British Information Services. The British recognised the commercial value of German scientific publishing, and Maxwell approached publisher Springer Verlag with an offer to distribute its publications outside of Germany. Given his connection with his British employer, Maxwell was in a position to help the company with essential supplies and to find ways through bureaucratic obstacles.

From here, Maxwell built up a commercial journal business that he eventually named Pergamon Press (see Cox, 1998). As UK and US technological nationalism grew in response to Soviet advances-most notably the Soviet launch of the Sputnik I satellite in 1957-Maxwell increasingly focused on journals that published cutting-edge scientific research. Pergamon Press grew increasingly profitable, and Maxwell invested in the acquisition of sophisticated distribution technology. Rather than the then-conservative focus of the learned society publishers on traditional subject areas, Pergamon Press collared papers on emerging fields such as atomic energy, bought up translation rights in Soviet journals, and, most important, supported the creation of large numbers of new journals in the emerging subject areas. Many of the journals that were created were called "The International Journal of ...", signalling the expansive imperial ambitions of the enterprise. Maxwell adopted new technologies as they arose, and invested in effective marketing. What had been a relatively amateur business sector grew rapidly and became professional big business.

\section{Scholarly journals and international power politics}

The journal publishing business also became a strategic tool for enhancing the power of knowledge in the building of enterprise in the two dominant English-speaking allies. This was a continuation of pre-war developments that linked research in telephony and communications, wireless and radar, transport, military equipment, and nuclear science, to the consolidation of commercial power in large nation-wide companies. In the US, in particular, with Vannevar Bush as a leading activist, this led to the creation of national scientific organisations dedicated to a strategic focus on leveraging science in the war effort. The atomic bomb was the spectacular pinnacle of these investments. Maxwell's capturing of the language hegemony in scientific publishing from Germany - a key element of the strategic development of Maxwell's journal business - thus bolstered the emergence of Britain and the US as the dominant powers in key strategic fields. Nationalistic hegemony came to be built into the journal business (Kleyn \& Nicholson, 2018).

\section{Metrics and rankings - leveraging author prestige}

Another important contribution by Maxwell to the journal system arose from his recognition that editors and authors had traditionally been undervalued by the learned societies, and authors who sought recognition for emerging disciplinary areas were marginalised. Maxwell's Pergamon Press was willing to spend money on attracting 
authors and editors: granting them a prestigious status, wining and dining them, empowering them, and supporting their ambitions. The company professionalised the production, marketing, and dissemination of the journals.

Maxwell anticipated the marketing potential of emerging tools such as the Science Citation Index, as developed in 1961 by Garfield's Institute for Scientific Information (ISI). This index, based on work started in 1955, enabled the development of journal bibliographic metrics to help librarians in their selection, for subscription purposes, from the ever-growing number of journals. Journal impact measures (e.g., the impact factor (IF), and then author citation counts), as competitive measures underpinning recognition and promotion, came later. (Impact factors were something that Garfield had not envisaged and did not entirely approve of.)

The ISI ranking system came to regard articles that addressed issues of concern to the UK and the US as capable of delivering impact-and thus status, to the journal concerned and, by extension, to the authors in that journal.

A publishing system that, in its pre-war incarnation, was neglectful of authors had now become excessively attentive to the desire of scholarly authors and their universities for prestige and status. The new system had also made scholarly authors captive to a promotion system delivered through citation counts linked to publication in the higher-ranking scholarly journals - a system upon which they became entirely dependent. What had emerged — and this is very familiar to us now-was a system whereby authors attained higher status and promotions through publishing in highly ranked journals (in topics that, in turn, added to the national and regional aspirations of the North Atlantic powers). At the same time, the cost of the journal subscriptions was not an issue that concerned the authors who drove support for the high-ranking journals - this was the burden of the libraries, essentially captives in a disjunctive business model in which they had to deliver to the desires of prestige- and promotion-hungry scholars.

After a turbulent financial history, Maxwell's journal empire eventually foundered and passed into other hands, finally being sold to Elsevier for USD770 million in 1991 to help fund his newspaper investments. But what Maxwell had been central to creating was a commercial academic publishing model with strong marketing and a high level of responsiveness to strategic developments in scholarship. He shrewdly understood the value that the competitive ranking systems would have for universities, scholarly authors, and their articles—a system that hooks the ecosystem's participants irretrievably into what is in fact a narrow and unreliable system that puts huge stress on library budgets, pushes scholarly books to the margins, and renders a swathe of development-focused and socially responsive research practically invisible. This is a distinctly commercial vision of the mission of academia. 
After Maxwell's death, the consolidation of large academic publishing companies increased, so that today there are essentially five huge journal companies that dominate the global scholarly publishing environment: Reed-Elsevier, Springer, Wiley-Blackwell, Taylor \& Francis, and Sage-in what is now one of the most profitable business sectors one can find. Digital media have helped to entrench the value system of the journal empires, offering even more streamlined and efficient online systems for leveraging the metrics that underpin the competitive system of author prestige and university rankings.

It is striking that the business models and strategic structuring of the dominant corporate journals remain very much an artefact of a post-Second World War environment, built on the dominance of the major Allied powers in an increasingly capitalist world. For developing-country universities, scholars, and journals excluded from this system, the need to join the dominant game and share in this "excellence" became irresistible. This has persisted to the present day. The journal system remains a colonised business, one that has to be played by the rules of international power politics, while the interests of the countries that were colonies when this business model was conceived remain at the margins.

\section{How Maxwell's legacy is experienced in sub-Saharan Africa}

At the time of Maxwell's creation of the journal business following the Second World War, sub-Saharan African countries were, with very few exceptions, still colonies, and universities were virtually non-existent. When, post-independence, sub-Saharan African universities began to emerge, they found themselves marginalised in the systems driving the journal publishing business—systems in which, still today, "global" impact tends to be defined in terms of the English language and the interests of the North Atlantic powers. In terms of the impact factor, achieving impact-the value according to which journals are ranked in importance and status and accepted as "quality" and "core" publications-essentially means focusing on topics of interest to North Atlantic powers. Subjects that concern "only" developing countries are regarded as "local". Tropical disease outbreaks, such as the Ebola epidemic that recently devastated West African countries, fall into this definition. (Sub-Saharan African nations were also penalised, in the latter decades of the 20th century, by World Bank policy (linked to structural adjustment programmes), which marginalised African higher education and devalued African research.)

In sub-Saharan Africa, the market for books has been fragmented by decades of territorial licensing. If an Anglophone African publisher has a title with potential beyond its national market, the title will most often be licensed to a UK publisher, which will claim "rest of the world" rights. Buyers in other African countries will then have to buy this UK "world" edition, at a very high cost, rather than the original African edition. Lower-cost "international student editions" are offered in African markets, on a discretionary basis, by UK and US publishers for some large-volume 
titles. For the rest of the UK and US titles, students have to pay the full US or UK price-a situation that applies particularly to upper-level specialist textbooks, which tend to be excluded from international rights arrangements or discretionary price reductions for smaller markets.

In the South African context, it is notable that a core point of contention in South African copyright lawmaking at present is the inclusion of "fair use" provisions in the 2017 Copyright Amendment Bill. The provisions in the Bill, which has yet to become law, are similar to those found in US copyright law. Fair use providesto a greater extent than the South African Act's existing "fair dealing" provisions, modelled on UK law-for copyright materials to be reproduced and used, without the permission of the copyright-holder, for limited purposes, including certain educational uses. The ultimate aim of provisions for US-style fair use and UK-style fair dealing is to balance the interests of society with those of rights-holders. The application of the South African Copyright Act's existing fair dealing provision has been found to be outdated and unable adequately to address the needs of a changing educational landscape that ever-increasingly includes digital components (Baude et al., 2006, pp. 83-84). The COVID-19 pandemic has made it particularly clear that restrictive licensing on ebooks and other increased transactional costs related to access to online materials has disproportionately benefited the rights-holders at the expense of students (Nicholson, 2020).

Public policy in South African jurisprudence is informed by the concept of ubuntu, which encompasses values of "humaneness, social justice and fairness" $(S v M a k-$ wanyane, para. 236). With this in mind and taking account of the constitutional obligation that falls on government to make education available and accessible to everyone, it would be incongruous to continue with the existing narrow copyright exceptions with respect to access to educational materials. The current system maintains the status quo, where textbooks and course materials are unaffordable for the majority of local students, while the same materials might cost significantly less in developed countries or other territories with which publishers have struck more generous trade agreements. For students in South Africa, as in the rest of the developing world, the result is one of academic exclusion, which stifles local development and innovation and perpetuates an unequal playing field (infojustice, 2019).

There are many in South Africa who believe the adoption of the proposed broader fair use provision in a new Copyright Act would be a welcome step towards providing more equitable local access to educational materials. However, international publishers-who stand to lose inflows of copyright licence fees, royalties, and other incomes-vehemently oppose this proposed change. A 2018 survey of 15 South African higher education institutions found that they were collectively paying approximately ZAR1 billion annually for access to copyright-protected digital and printed resources (Kleyn \& Nicholson, 2018). It was estimated that $80 \%$ of this total consist- 
ed of fees paid to international publishers. A further ZAR31 million was being paid to the South African copyright collection society, DALRO (Dramatic, Artistic and Literary Rights Organisation), in the form of licensing fees for copyright-protected prescribed course materials, with the lion's share of the DALRO fees being paid to international publishers and authors (Gray \& Czerniewicz, 2018, p. 134). It is crucial to keep in mind that these fees are mostly public funds-i.e., they are fees paid by public universities. These fees represent funds that are not being used, as they should be, to grow local publishing or to reinvest in public education. Also highly problematic is the fact that the majority of these fees sit with the collecting publishers and do not find their way to the original creators and authors (Kleyn \& Nicholson, 2018).

If a true decolonisation of South African and other sub-Saharan African educational institutions is to occur, then discordant economic relationships of the sort just outlined must be critically re-examined. The genesis of the current South African Copyright Act was in colonial legislation, which has subsequently been adapted and largely influenced by the Berne Convention (which itself drew significantly from UK legislation and was comprised of a homogeneous European group). Thus it is arguably high time that new legislation is introduced which prioritises local needs and objectives. IP regimes in African countries, as with the scholarly publishing ecosystems, have for too long been underpinned by neo-colonial arrangements. Change will require a move from rigid exclusion to flexible and dynamic inclusion, so as to foster publishing and IP ecosystems that support both developing-world and developed-world scholarship, national ambitions, technological innovation, commercial growth, and sustainable socio-economic development.

\section{References}

Baude, W., Hofman, J., Katz, E., McDaniel, K., Res, A., \& Riley, C. (2006). Model language for exceptions and limitations to copyright concerning access to learning materials in South Africa. The Southern African Journal of Information and Communication (SAJIC), 7, 82-106. https://doi.org/10.23962/10539/19800

Cox, B. (1998). The Pergamon phenomenon, 1951-1991: A memoir of the Maxwell years. Logos: The Journal of the World Book Community, 9(3), 135-140.

Gray, E., \& Czerniewicz, L. (2018). Access to learning resources in post-apartheid South Africa. In J. Karaganis (Ed.), Shadow Libraries - Access to knowledge in global higher education. MIT Press. https://direct.mit.edu/books/book/3600/chapter/120594/ Access-to-Learning-Resources-in-Post-apartheid

Henderson, A. (2004). The dash and determination of Robert Maxwell: Champion of dissemination. Logos: The Journal of the World Book Community, 15(2), 63-74.

infojustice (2019, August 16). Decolonising copyright: Building our creative and information economy. http://infojustice.org/archives/41492

Kleyn, L., \& Nicholson, D. (2018, October 26). The cost of accessing academic research is way too high. This must change. world.edu. https://www.world.edu/the-cost-ofaccessing-academic-research-is-way-too-high-this-must-change 
Nicholson, D. (2020, July 18). COVID and copyright - impact on education and libraries in South Africa. infojustice. http://infojustice.org/archives/42517

Republic of South Africa (RSA). (2017). Copyright Amendment Bill. https://libguides.wits. ac.za/ld.php?content $\mathrm{id}=45613747$

Sv Makwanyane and Another (CCT3/94) [1995] ZACC 3; 1995 (6) BCLR 665; 1995 (3) SA 391; [1996] 2 CHRLD 164; 1995 (2) SACR 1 (6 June 1995) 